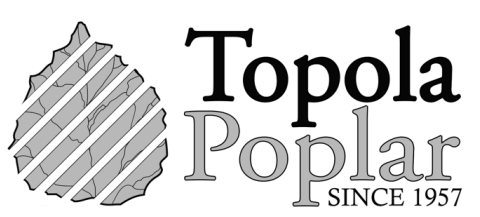

UDC: $630 * 2: 582.681 .81$

Original scientific paper

\title{
Survival and Growth of White Poplar Rooted Cuttings Regarding Term of Planting
}

\author{
Branislav Kovačević ${ }^{1, *}$, Dušan Igić ${ }^{2}$, Zoran Novčić ${ }^{1}$, Saša Orlović ${ }^{1}$ \\ 1 University of Novi Sad, Institute of Lowland Forestry and Environment, Novi Sad, Serbia \\ 2 Public Enterprise "Vojvodinašume", Petrovaradin, Serbia \\ * Corresponding author: Branislav Kovačević; E-mail: branek@uns.ac.rs
}

Received: 11 May 2020; Revised: 22 May 2020; Accepted: 27 May 2020

\begin{abstract}
White poplar nursery production is mainly based on vegetative propagation hardwood cuttings. In this study the reaction of three clones of white poplar (Populus alba L.) on term of cuttings' preparation and planting according to parameters of survival and growth of rooted cuttings in three nurseries in Northern part of Serbia. There were two terms of cuttings' preparation and planting examined: a) mid-March and d) the beginning of April (standard term). Obtained results suggest considerable differences between nurseries and between examined terms. Differences between clones were not significant, but there were found significant effects of interactions of factor Clone with other two main sources of variation. The best results were obtained by cuttings that were prepared and planted in mid-March, due to faster growth and survival of rooted cuttings. The positive effect of the earlier term is evident particularly in clones L-12 and L-80 and enable feasible production of rooted cuttings of these clones, especially in nurseries that obtained better conditions. Results obtained in this study suggest that influence of terms of cuttings' production and planting is important issue concerning introduction of clones with relatively poor rooting capacity, optimization of nursery technology of experimental white poplar clones, and improvement of white poplar nursery production in general.
\end{abstract}

Keywords: Populus alba, clonal technology, cuttings' management.

\section{Introduction}

White poplar (Populus alba L.) is fast-growing, adoptable tree species, usually mixed with European black poplar and broadly used in afforestation of riparian zones (Rončević et al. 2012). More abundant in the past (Redei et al. 2010), it is now threatened species, used as a marker of biodiversity (Kovačević et al. 2010). Nowadays, white poplar also receives more attention in terms of wood physical and mechanical properties (Ištok et al. 2019; Sedlar et al. 2019). However, the main obstacle in the improvement of white poplar wood production is generally poor hardwood cuttings' rooting. Lack of feasible means of vegetative propagation of suppresses use of genotypes that are superior by other important characteristics such as: growth, tree shape and tolerance to abiotic and biotic factors. That is why successful rooting of hardwood cuttings is one of the main goals in white poplar breeding (Guzina, 1986). 
There is constant need to improve poplar nursery technology in general and to adjust it to the specificities of interesting genotypes, which is especially challenging in case of white poplar (Kovačević et al. 2002; Kovacevic et al. 2008a; Kovačević et al. 2014; Kovačević and Igić, 2018; Nonić et al. 2019; Igić et al. 2020). The main effort is directed to activation of pre-formed primordia which is crucial step in early phases of the formation of root system and further cuttings' survival (Smith and Wareing, 1972; Kovacevic et al. 2009; Zhao et al. 2014). In spite wellknown importance of auxins in control of cuttings' rooting (Pacurar et al. 2014), results of Kovačević et al. (2014) and Igić et al. (2020) suggest that effects of rooting stimulation with indolbutiric acid is considerably dependent on clones and soil properties.

Beside hormonal stimulation, numerous factors influence rooting of poplar hardwood cuttings and could be varied in order to optimize this process (Fege, 1983; Kovacevic et al. 2008a). On their work on Eucaliptus and Populus species, De Almeida et al. (2017) suggested control of irradiance, temperature, water availability, mineral nutrition and beneficial root-associated microorganisms. According to Eggens et al. (1972), there is difference in physiological status throughout the dormant period in white poplar shoots and cuttings prepared from them, suggesting differences in the rooting ability of cuttings produced in different terms of dorman period. Andrašev et al. (2006) and Kovačević et al. (2006) found significant effect of date of preparation and date of planting of black poplar cuttings on their survival and rooting. Also, beside significant effect of slope orientation Kovačević and Igić (2018) found that term of cuttings preparation achieved significant influence on survival and growth of white poplar rooted cuttings planted at the beginning of April.

In this research, we studied the influence of cuttings' preparation and planting term of three white poplar clones in three nurseries. The aim is to evaluate and relate the importance of these factors on white poplar cutting survival and further growth of rooted cuttings in examined clones.

\section{Material and methods}

There were two types of nursery trials: one for examination of survival and growth of rooted cuttings, and the other for examination of early formation of shoot and root system. The nursery trials studying survival and growth of rooted cuttings were established in three sites: two in nurseries of Public Enterprise "Vojvodinašume": "Hrastovača", near Subotica $\left(46^{\circ} 09^{\prime} 12^{\prime \prime} \mathrm{N} 19^{\circ} 40^{\prime} 06^{\prime \prime} \mathrm{E}\right)$ and "Ratno ostrvo", near Novi Sad (45 $\left.17^{\prime} 05^{\prime \prime} \mathrm{N} 19^{\circ} 54^{\prime} 38^{\prime \prime} \mathrm{E}\right)$ and one in Experimental forest estate “Kaćka šuma", near Novi Sad $\left(45^{\circ} 17^{\prime} 39^{\prime \prime} \mathrm{N} 19^{\circ} 53^{\prime} 16^{\prime \prime} \mathrm{E}\right)$ managed by Institute of lowland forestry and environment, University of Novi Sad. Trial in nursery "Hrastovača" was established on sandy arenosol, in nursery "Ratno ostrvo" on loamy fluvisol and in "Kaćka šuma" on loamy humofluvisol. Four genotypes were examined: Italian clone Populus alba cl. Villafranca, and two experimental Serbian selections: P. alba cl. L-12 and P. alba cl. L-80.

All trials were designed to examine the effect of term of cuttings' preparation and planting were established in all three nurseries. There were two terms of cuttings' preparation and planting examined: a) mid-March and b) the beginning of April. The trials for studying survival and growth of rooted cuttings were designed as completely randomized, with six repetitions in trial in "Hrastovača", twelve repetitions in trial in "Ratno ostrvo" and three repetitions in trial in "Kaćka šuma". There were fifty planted cuttings per plot. The trials were mechanically weeded and irrigated when it was necessary throughout the growing season. Height and survival of rooted cuttings were measured in the mid-October 2019. Also, the following parameters were derived at the level of plot: the mean height of the rooted cutting ( $\mathrm{SH})$, the percentage of survived cuttings (SURV), c) the percentage of cuttings that gave plants higher than $180 \mathrm{~cm}$ (SURV180) and gave plants higher than $250 \mathrm{~cm}$ (SURV250). These data were the basis for further statistical analysis. 
In the nursery "Kaćka šuma" the trial for research on early growth and development of shoot and root system was established in order to study the difference in reaction of examined white poplar clones by their rooting characters. The same terms of cuttings' production and planting as well as same three white poplar clones were studied. Forty cuttings per clone were planted per plot. At mid-June the vital rooted cuttings were dug up and following characters were measured: LN - number of leaves; $\mathrm{SH}$ - shoot height; $\mathrm{R} 0$ - number of roots on basal cut; R05 - number of roots from basal cut to $5^{\text {th }} \mathrm{cm}$ from base of cutting, R5 - number of roots below $5^{\text {th }} \mathrm{cm}$ from the base of cutting; R510 - number of roots from $5^{\text {th }}$ to $10^{\text {th }} \mathrm{cm}$ from the base of cutting; R1020 - number of roots from $10^{\text {th }} \mathrm{cm}$ to the top of cutting. From these measured characters following traits were calculated: TRN - total number of roots; R0p - partition of number of roots on basal cut in total number of roots; R05p - partition of number of roots from basal cut to $5^{\text {th }} \mathrm{cm}$ from base of cutting in total number of roots, $\mathrm{R} 5 \mathrm{p}$ - partition of number of roots below $5^{\text {th }} \mathrm{cm}$ from the base of cutting in total number of roots; R510p - partition of number of roots from $5^{\text {th }}$ to $10^{\text {th }} \mathrm{cm}$ from the base of cutting in total number of roots; R1020 - partition of number of roots from $10^{\text {th }} \mathrm{cm}$ to the top of cutting in total number of roots.

Factorial two and three-way analysis of variance were used for most of examined trait, Repeated measures analysis of variance for partition of cuttings with vital shoot, while the significance of differences between means of treatments was tested by Tukey's HSD (honestly significant difference) test. All parameters expressed in percentages were transformed by arcsintransformation $(\arcsin \sqrt{x})$ in order to meet normal distribution of frequencies and assumptions for used methods of parametric statistics. For the same reason, number of leaves and all parameters describing number of roots of certain part of cutting were transformed by square transformation $(\sqrt{x+1})$. All statistical procedures were performed by statistical package STATISTICA (TIBCO Software Inc., 2017).

\section{Results and discussion}

\subsection{Dynamics of the rate of cuttings with vital shoot}

According to the measurements of partition of cuttings with vital shoot, cuttings from both planting term treatments achieved the maximum in $8^{\text {th }}$ May. At $11^{\text {th }}$ April, four weeks after the planting, treatment planted in March reached percentage of cuttings with vital shoots at the level of maximum for cuttings planted in April. In next four weeks it achieved its maximum, which appeared to be twice as maximum of treatment planted in April. After $8^{\text {th }}$ May, for both planting term treatments, the percentage of cuttings with vital shoots decreased until $11^{\text {th }}$ June. This drop counted over $20 \%$ after both terms of cuttings' preparation and planting. According to Kovačević et al. (2009), this decrease of the percentage of cuttings with vital is result of lack of balance in growth and development of shoot and root system that occurs at the beginning of cuttings' rooting. According to Tukey's test based on Repeated measures analysis of variance, as well as considering importance for nursery production, from $11^{\text {th }}$ June on this parameter is not significantly higher than in October (Figure 1). Similar results were obtained by Kovacevic et al. (2009), who recorded that the period from cuttings planting (beginning of April) until the second decade of June were crucial for the survival of black poplar rooted cuttings.

\subsection{Effect of terms on survival and growth of white poplar rooted cuttings}

Parameters describing survival and growth of rooted cuttings of examined clones were measured in trials in all three nurseries. According to the F-test, factors Nursery and Term of cuttings preparation and planting, as well as interactions Nursery $\times$ Term and Nursery $\times$ Clone achieved significant effects on variation of all studied parameters. Factor Clone achieved 
significant effect on partition of rooted cuttings higher than $180 \mathrm{~cm}$ as well as on partition of rooted cuttings higher than $250 \mathrm{~cm}$. The only significant effect of interaction Term $\times$ Clone was found in shoot height, and the only significant effect of interaction Nursery $\times$ Term $\times$ Clone was found in cuttings' survival (Table 1).

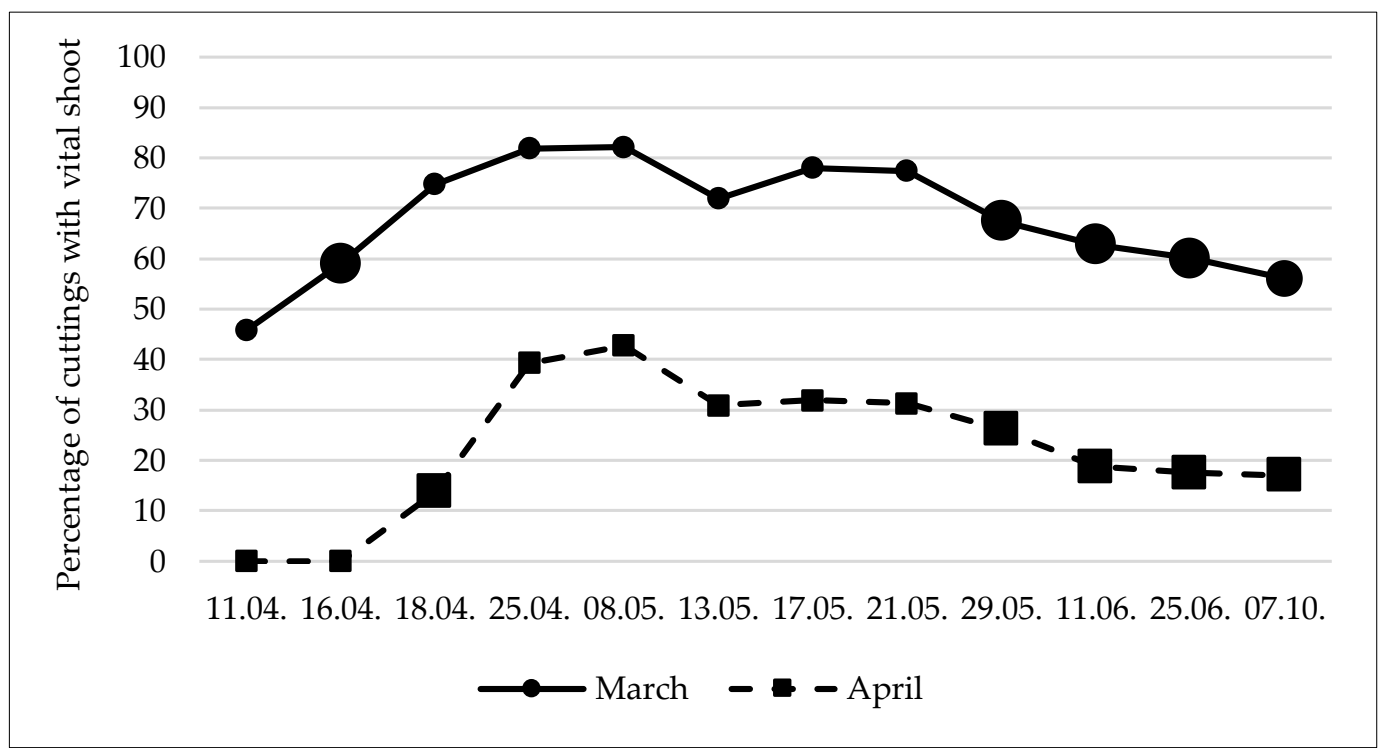

*) Bigger points reveal values that do not significantly differ than measurement in October according to Tukey's test at the level of $\alpha=0.05$

Figure 1. Partition of cuttings with vital shoot regarding term of cuttings' preparation and planting *)

The effect of examined sources of variation is also described by contributions to the total expected variance. The highest contribution achieved differences between nurseries in all examined traits, except for cuttings' survival where interaction Nursery $\times$ Term dominated (Figure 2).

Table 1. F-test from three-way analyses of variance for growth and survival characters in examined white poplar clones.

\begin{tabular}{lcrrr}
\hline $\begin{array}{c}\text { Sources of } \\
\text { variation }\end{array}$ & $\begin{array}{c}\text { Shoot } \\
\text { height }\end{array}$ & $\begin{array}{c}\text { Cuttings' } \\
\text { survival }\end{array}$ & $\begin{array}{c}\text { Partition of rooted } \\
\text { cuttings higher than } \\
\mathbf{1 8 0} \mathbf{~ c m}\end{array}$ & $\begin{array}{c}\text { Partition of rooted } \\
\text { cuttings } \\
\text { higher than } \mathbf{2 5 0 ~} \mathbf{~ c m}\end{array}$ \\
\hline Nursery (A) & $467.488^{* *}$ & $32.435^{* *}$ & $496.724^{* *}$ & $147.168^{* *}$ \\
Term (B) & $7.794^{* *}$ & $26.513^{* *}$ & $37.494^{* *}$ & $51.850^{* *}$ \\
Clone (C) & $2.198^{* *}$ & $2.129^{* *}$ & $4.461^{*}$ & $5.488^{* *}$ \\
Interaction $\mathrm{A} \times \mathrm{B}$ & $7.723^{* *}$ & $24.001^{* *}$ & $22.568^{* *}$ & $13.972^{* *}$ \\
Interaction $\mathrm{A} \times \mathrm{C}$ & $3.543^{* *}$ & $6.311^{* *}$ & $8.520^{* *}$ & $9.264^{* *}$ \\
Interaction $\mathrm{B} \times \mathrm{C}$ & $4.213^{*}$ & $2.618^{*}$ & 2.864 & 1.066 \\
Interaction $\mathrm{A} \times \mathrm{B} \times \mathrm{C}$ & 0.230 & $6.450^{* *}$ & 0.978 & 0.389 \\
\hline
\end{tabular}

Labels for F-test: * - significant at the level $\alpha=0.05 ;{ }^{* *}$ - significant at the level $\alpha=0.01$ 
Factor Term of preparation and planting of cuttings achieved considerable effect on variation of cuttings' survival and partition of rooted cuttings higher than $250 \mathrm{~cm}$ (more than $10 \%)$. However, the effect of factor Clone was poor. The influence of clones only manifested through considerable contribution of interaction Nursery $\times$ Clone in cuttings' survival and partition of rooted cuttings higher than $250 \mathrm{~cm}$, as well as through interaction Nursery $\times$ Term $\times$ Clone. Significant differences between nurseries in cutting's survival of white poplar were also found by Kovačević et al. (2014). Significant effect of factor nursery as well as of its first-order interactions suggest considerable importance of proper selection of site for nursery establishment, as well as of adequate nursery technology for successful nursery production of white poplar rooted cuttings.

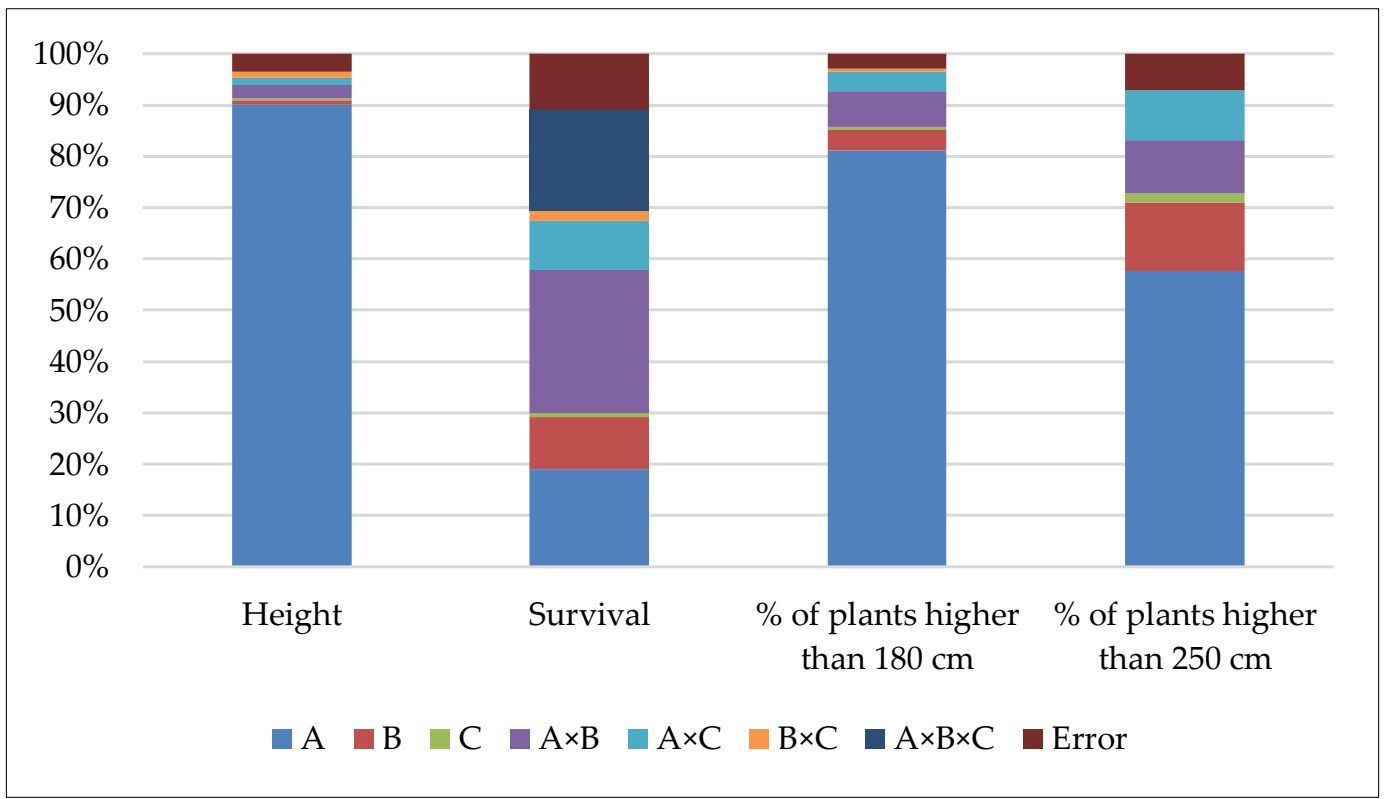

Labels for Legend (Sources of variation): A - Nursery, B - Term of cuttings' preparation and planting, C-Clone, $\mathrm{A} \times \mathrm{B}$ - interaction Nursery $\times$ Term, $\mathrm{A} \times \mathrm{C}$ - interaction Nursery $\times$ Clone, $\mathrm{B} \times \mathrm{C}$ interaction Term $\times$ Clone, $\mathrm{A} \times \mathrm{B} \times \mathrm{C}$ - interaction Nursery $\times$ Term $\times$ Clone

Figure 2. Contribution of expected variances of examined sources of variation to the total expected variance for growth and survival characters in examined white poplar clones.

The strong effect of factor Nursery was expected since the soil texture varied from sandy in nursery "Hrastovača" (Kovačević et al. 2014), to loamy sand in nurseries "Kaćka šuma" (Kovačević et al, 2010) and "Ratno ostrvo" (Kovačević and Igić, 2018). According to the results of Tukey's HSD test (Table 2), the highest rooted cuttings were produced in nurseries "Ratno ostrvo" and "Kaćka šuma", and the smallest (more than 2 times smaller than the previous two nurseries) in "Hrastovača". These results suggest difficulties in nursery "Hrastovača" to produce rooted cuttings higher than $180 \mathrm{~cm}$ in one year, and rooted cuttings shorter than $180 \mathrm{~cm}$ are not considered to be appropriate for planting. So, these plants need one more growing season to exceed this height limit.

The differences between nurseries were relatively smaller in cuttings survival, yet considerable. The greatest cuttings' survival was recorded in nursery "Ratno ostrvo" and the smallest in "Kaćka šuma". The poor survival gained in "Kaćka šuma" is primarily consequence of rather poor survival after later planting term (the beginning of April). Considering the importance of initial soil temperatures for poplar cuttings' rooting (Zalesny et al. 2004; Zalesny et al. 2005), relatively good cuttings' survival in "Hrastovača" could be related to expected 
quicker heating of sandy soil combined with higher than average monthly temperatures at the beginning of growing season (Republic Hydrometeorological Service of Serbia, 2020). However, due to slow growth of rooted cuttings, the participation of rooted cuttings higher than $180 \mathrm{~cm}$ as well as of those higher than $250 \mathrm{~cm}$ were the smallest in "Hrastovača". On the other side, more than $50 \%$ of planted cuttings in nursery "Ratno ostrvo" gave plants higher than $180 \mathrm{~cm}$ (that satisfy standards for the afforestation), with more than $20 \%$ of planted cuttings that gave the first class plants (higher than $250 \mathrm{~cm}$ ), which could be considered as very good result in production of one-year old white poplar rooted cuttings.

According to Tukey's tests for examined parameters, survival and growth of rooted cuttings after earlier term of cuttings' preparation and planting were significantly better. The highest effect was found in rate of cuttings' survival and participation of plants higher than 250 $\mathrm{cm}$ which was three times higher after late than after early term. According to report of measurements in the vicinity of nurseries for March and April of 2019, the mean monthly precipitations were below and temperatures were above their climate normals, especially in March, while in May precipitations were above and temperatures below average (Republic Hydrometeorological Service of Serbia, 2020). According to the same report the year 2019. was the extremely hot in almost all meteorological stations in Serbia. The drought in March and April was not favorable for cuttings' survival but high temperatures and use of irrigation system probably contributed to relatively good overall cuttings' survival. Significant positive effect gained after early cuttings' preparation and planting, suggest that the term of middle March is not only at the level, but even more feasible than usually used term of the beginning of April. However, the effect was not significant in all nurseries, which support highly significant results of F-tests for the effect of interaction Nursery $\times$ Term in all examined parameters. There were not found significant differences between two terms in nursery "Hrastovača" for any of examined survival and growth parameters. However, in other two nurseries all parameters except height in nursery "Kaćka šuma" were significantly different between two examined terms. In nursery "Ratno ostrvo" almost $60 \%$ of cuttings gave plants that satisfy demands for afforestation (higher than $180 \mathrm{~cm}$ ), and more than 30\% gave the first-class plants (higher than $250 \mathrm{~cm}$ ) after early term of cuttings' preparation and planting. This suggest that it is possible in this nursery to achieve relatively feasible production of one-year old rooted cuttings of examined clones that are appropriate for plantation establishment.

Although significant effect of factor Clone calculated by F-test, according to Tukey's HSD test differences between examined clones were not significant. Also, although the interaction Nursery $\times$ Clone was significant for all examined traits, there were no differences between clones within nurseries by examined traits except for significantly higher cuttings' survival and partition of rooted cuttings higher than $180 \mathrm{~cm}$ and $250 \mathrm{~cm}$ in Villafranca comparing to other two clones in nursery "Kaćka šuma" (Table 2).

The only trait with significant effect of interaction Term $\times$ Clone was plants' height, mostly because only plants of clone L-80 grown from cuttings planted in mid-March were significantly higher than from those planted at the beginning of April. Such differences were not found in Villafranca and L-12. In case of other traits, all examined clones reacted positively on earlier term which favors this term of cuttings' preparation and planting.

Significant effect of interaction Nursery $\times$ Term $\times$ Clone found for cuttings' survival, was confirmed with Tukey's HSD test. There were significantly higher cuttings' survival in clone Villafranca than in clone L-80 after mid-March term of cuttings' preparation and planting in nursery "Kaćka šuma" and after later examined term in nursery "Ratno ostrvo". There were also found significant differences between terms in some clones. Clones L-12 and Villafranca had significantly higher cuttings' survival after early than after late term of cuttings' preparation and planting in nursery "Kaćka šuma", but clone L-12 achieved opposite result in nursery "Hrastovača". 
Table 2. Tukey's HSD test for examined growth and survival parameters of studied white poplar clones

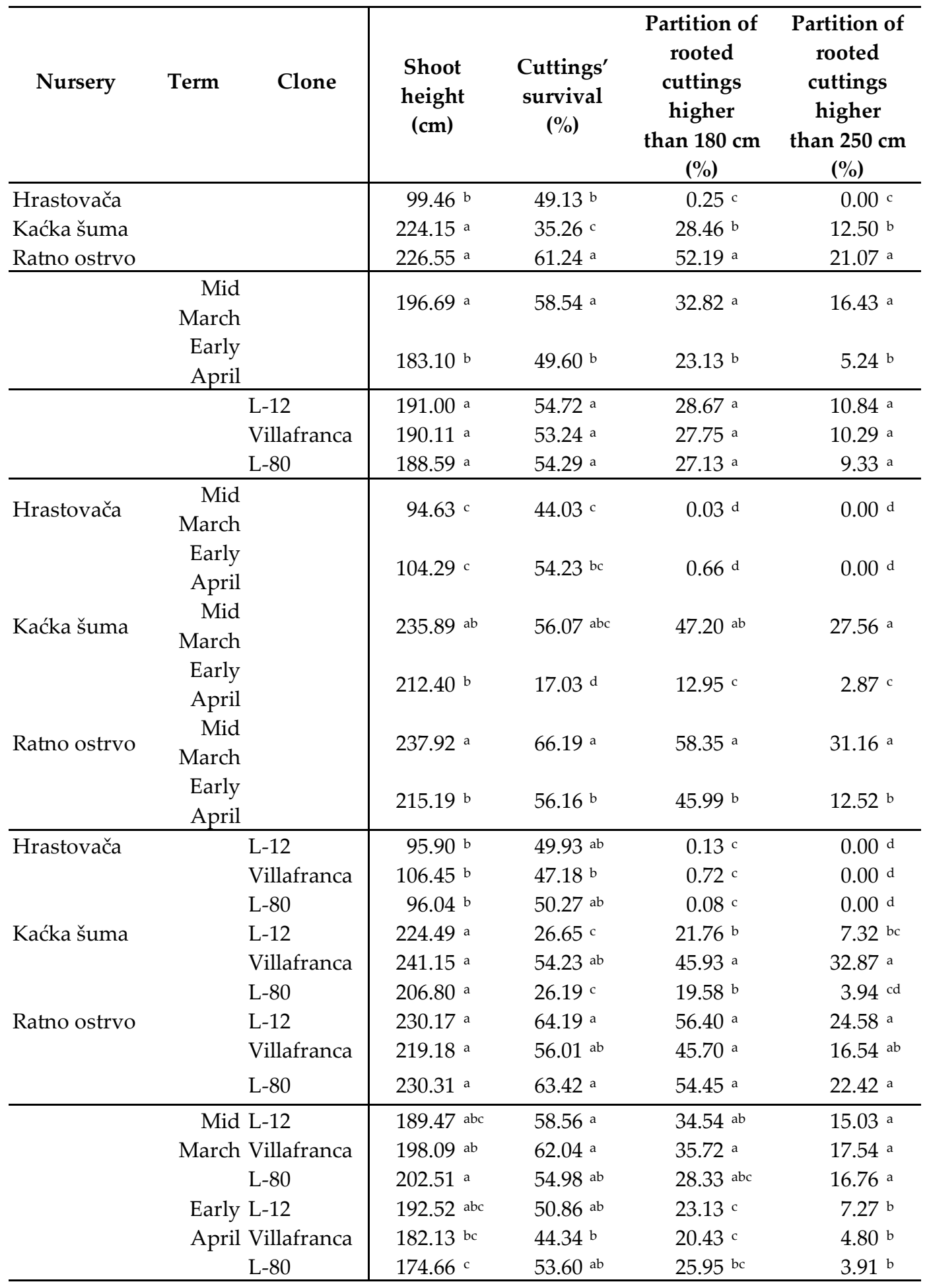

Labels for Tukey's HSD test: difference between values with the same letter is not significant at the level $\alpha=0.05$ 
Table 2. Continue.

\begin{tabular}{|c|c|c|c|c|c|}
\hline Nursery & Clone & $\begin{array}{l}\text { Shoot } \\
\text { height } \\
\text { (cm) }\end{array}$ & $\begin{array}{c}\text { Cuttings' } \\
\text { survival } \\
(\%)\end{array}$ & $\begin{array}{l}\text { Partition of } \\
\text { rooted } \\
\text { cuttings } \\
\text { higher } \\
\text { than } 180 \mathrm{~cm} \\
(\%) \\
\end{array}$ & $\begin{array}{c}\text { Partition of } \\
\text { rooted } \\
\text { cuttings } \\
\text { higher } \\
\text { than } 250 \mathrm{~cm} \\
(\%) \\
\end{array}$ \\
\hline \multirow[t]{6}{*}{ Hrastovača } & Mid L-12 & $85.04 \mathrm{~d}$ & 32.61 ef & $0.00^{\mathrm{f}}$ & $0.00 \mathrm{~g}$ \\
\hline & March Villafranca & $103.10^{\mathrm{d}}$ & 47.48 bcde & 0.29 ef & $0.00 \mathrm{~g}$ \\
\hline & L-80 & $95.76^{\mathrm{d}}$ & 52.32 abcde & $0.00 \mathrm{f}$ & $0.00 \mathrm{~g}$ \\
\hline & Early L-12 & $106.75 \mathrm{~d}$ & $67.26 \mathrm{abcd}$ & 0.51 ef & $0.00 \mathrm{~g}$ \\
\hline & April Villafranca & $109.80 \mathrm{~d}$ & 46.88 bcde & 1.34 ef & $0.00 \mathrm{~g}$ \\
\hline & L-80 & $96.33 \mathrm{~d}$ & 48.21 bcde & 0.33 ef & $0.00 \mathrm{~g}$ \\
\hline \multirow[t]{6}{*}{ Kaćka šuma } & Mid L-12 & $225.09 a b c$ & 51.67 abcde & $42.47 \mathrm{abc}$ & 16.60 bcde \\
\hline & March Villafranca & $258.21 \mathrm{ab}$ & $76.99 \mathrm{ab}$ & 68.78 a & 55.34 a \\
\hline & L-80 & $224.37 \mathrm{abc}$ & 38.19 cdef & $30.44 \mathrm{bcd}$ & 15.13 bcde \\
\hline & Early L-12 & $223.89 \mathrm{abc}$ & $7.79 \mathrm{f}$ & 6.64 def & 1.63 efg \\
\hline & April Villafranca & $224.09 \mathrm{abc}$ & 30.49 ef & $23.94 \mathrm{~cd}$ & 13.91 bcdef \\
\hline & L-80 & $189.24^{\mathrm{c}}$ & $15.76^{\mathrm{f}}$ & 10.64 de & $0.00 \mathrm{fg}$ \\
\hline \multirow[t]{6}{*}{ Ratno ostrvo } & Mid L-12 & $232.78 \mathrm{abc}$ & 72.67 a & 63.48 a & $31.12 \mathrm{ab}$ \\
\hline & March Villafranca & $230.55 \mathrm{abc}$ & 65.17 abcd & $56.411^{a}$ & $27.01 \mathrm{abc}$ \\
\hline & L-80 & 250.42 a & 60.46 abcd & $55.07 \mathrm{ab}$ & $35.50 \mathrm{ab}$ \\
\hline & Early L-12 & $227.56 \mathrm{abc}$ & 55.24 abcde & $49.18 \mathrm{abc}$ & $18.58 \mathrm{bcd}$ \\
\hline & April Villafranca & $207.81^{c}$ & 46.65 de & $35.18^{c}$ & 8.24 def \\
\hline & L-80 & $210.19 \mathrm{bc}$ & $66.33 \mathrm{abc}$ & $53.83 \mathrm{ab}$ & 11.64 cde \\
\hline
\end{tabular}

Labels for Tukey's HSD test: difference between values with the same letter is not significant at the level $\alpha=0.05$

Although not confirmed by F-test interaction Nursery $\times$ Term $\times$ Clone, according to Tukey's HSD test, Villafranca achieved significantly higher partition of plants higher than 180 $\mathrm{cm}$ and of those higher than $250 \mathrm{~cm}$ after early than after late examined term of cuttings' preparation and planting.

Thus, considering obtained results on survival and growth of rooted cuttings nursery characteristics are of considerable importance for successful nursery production of examined white poplar clones. Influence of term of cuttings' preparation and planting was not as critical, but early term (mid-March) appeared to be at least as feasible as the late term (beginning of April), and in some cases even better, which should be tested in further studies.

\subsection{Effects of terms of cuttings' preparation and planting on rooting parameters}

According to the results of two-way analysis of variance, there were differences in influence of controlled source of variance on variation of rooting parameters examined in midJune in trial established in nursery "Kaćka šuma" (Table 3). Most of parameters were significantly influenced by at least one of examined sources of variance, except for R05p. The greatest F-values (more than 10) for factor Clone were found for TRN, R0 and R05. According to Tukey's HDS test, clone L-80 had the highest number of roots in total and in basal part of cutting and clone Villafranca the lowest. However, the clone Villafranca achieved the highest cuttings' survival, suggesting that the influence of other traits on survival of white poplar cuttings should be examined as well. For example, clone Villafranca achieved the greatest partition of number of 
roots on upper part of cutting (R1020p), and the lowest partition of roots from basal cut to $5^{\text {th }} \mathrm{cm}$ of cutting (R05p) suggesting the importance of the activation of rooting primordia in upper part of cutting.

The greatest F-values (around and more than 10) for factor Term were found for characters SH, R0, R0p and TRN, and all these characters had significantly higher values after cuttings' preparation and planting in mid-March than at the beginning of April. So, the general response on early comparing to late term is in course of overall increment of vigor and vitality of rooted cuttings as well as increment of rooting at the basal part of cutting, but not towards uniform rooting along the cutting, as it was found for examined clones.

Table 3. F-test from two-way analysis of variance and Tukey's HSD test for examined parameters of root formation in studied white poplar clones.

\begin{tabular}{|c|c|c|c|c|c|c|c|c|}
\hline & & LN & SH & R0 & R05 & R5 & R510 & R1020 \\
\hline \multicolumn{9}{|c|}{ F-test } \\
\hline \multicolumn{2}{|l|}{ Clone (A) } & $6.67^{* *}$ & 2.62 & $10.00 * *$ & $11.20^{* *}$ & $9.44^{* *}$ & $5.44^{* *}$ & 1.32 \\
\hline \multicolumn{2}{|l|}{ Term (B) } & $8.59 * *$ & $12.63^{* *}$ & $13.77^{* *}$ & 0.43 & $8.77^{* *}$ & 0.02 & 3.32 \\
\hline \multicolumn{2}{|c|}{ Interaction $\mathrm{A} \times \mathrm{B}$} & 0.26 & $8.13^{* *}$ & $11.27^{* *}$ & $10.99^{* *}$ & $13.92 * *$ & 2.09 & $4.38 *$ \\
\hline \multicolumn{9}{|c|}{ Tukey's HSD-test } \\
\hline Villafranca & & $18.61 \mathrm{~b}$ & $33.81^{a}$ & $6.40^{b}$ & $1.45 \mathrm{~b}$ & 7.87 b & $1.82 \mathrm{~b}$ & $2.14^{\mathrm{a}}$ \\
\hline $\mathrm{L}-12$ & & $18.39 \mathrm{~b}$ & $32.04{ }^{a}$ & $4.68^{b}$ & $2.11 \mathrm{ab}$ & $7.16^{b}$ & $1.73 \mathrm{~b}$ & 1.81 a \\
\hline \multirow[t]{3}{*}{ L-80 } & & 23.09 a & 35.82 a & 9.96 a & 2.94 a & 13.03 a & 2.90 a & $1.84^{\mathrm{a}}$ \\
\hline & $\begin{array}{l}\text { Mid } \\
\text { March }\end{array}$ & $21.44^{\text {a }}$ & 37.54 a & 8.57 a & $2.11^{a}$ & $10.86^{a}$ & 2.17 a & $2.14^{a}$ \\
\hline & $\begin{array}{l}\text { Early } \\
\text { April }\end{array}$ & $18.06^{b}$ & $28.79 \mathrm{~b}$ & $5.01 \mathrm{~b}$ & $2.11^{a}$ & $7.22 \mathrm{~b}$ & $2.12 \mathrm{a}$ & $1.67 \mathrm{a}$ \\
\hline \multirow[t]{2}{*}{ Villafranca } & $\begin{array}{l}\text { Mid } \\
\text { March }\end{array}$ & $21.21 \mathrm{ab}$ & 44.88 a & 12.49 a & $2.11 \mathrm{bc}$ & 14.66 a & $2.27 \mathrm{ab}$ & 3.01 a \\
\hline & $\begin{array}{l}\text { Early } \\
\text { April }\end{array}$ & $16.53 \mathrm{~b}$ & $24.40^{c}$ & $2.65^{c}$ & $0.94^{c}$ & $3.61^{c}$ & $1.47 \mathrm{~b}$ & $1.48^{b}$ \\
\hline \multirow[t]{2}{*}{ L-12 } & $\begin{array}{l}\text { Mid } \\
\text { March }\end{array}$ & $19.09 \mathrm{ab}$ & $34.38 \mathrm{abc}$ & $5.72 \mathrm{bc}$ & $2.08^{b}$ & $8.08 \mathrm{bc}$ & $1.71^{\mathrm{b}}$ & $1.98 \mathrm{ab}$ \\
\hline & $\begin{array}{l}\text { Early } \\
\text { April }\end{array}$ & 14.93 b & $19.75 \mathrm{bc}$ & $0.66^{c}$ & $2.24 \mathrm{abc}$ & $3.15 \mathrm{bc}$ & $1.83 \mathrm{ab}$ & $1.00 \mathrm{ab}$ \\
\hline \multirow[t]{2}{*}{ L-80 } & $\begin{array}{l}\text { Mid } \\
\text { March }\end{array}$ & 24.41 a & $34.47 \mathrm{abc}$ & $8.79 \mathrm{ab}$ & $2.13 \mathrm{~b}$ & $10.98 \mathrm{ab}$ & $2.63 \mathrm{ab}$ & $1.60 \mathrm{ab}$ \\
\hline & $\begin{array}{l}\text { Early } \\
\text { April }\end{array}$ & $21.35 \mathrm{ab}$ & $37.64 \mathrm{ab}$ & $11.65 \mathrm{ab}$ & 4.19 a & 16.09 a & $3.28 \mathrm{a}$ & $2.19 a b$ \\
\hline
\end{tabular}

Labels of traits: LN - number of leaves; $\mathrm{SH}$ - shoot height; $\mathrm{R} 0$ - number of roots on basal cut; R05 - number of roots from basal cut to $5^{\text {th }} \mathrm{cm}$ from base of cutting, R5 - number of roots below $5^{\text {th }} \mathrm{cm}$ from the base of cutting; R510 - number of roots from $5^{\text {th }}$ to $10^{\text {th }} \mathrm{cm}$ from the base of cutting; R1020 - number of roots from $10^{\text {th }} \mathrm{cm}$ to the top of cutting

Labels for F-test: * - significant at the level $\alpha=0.05 ;{ }^{* *}$ - significant at the level $\alpha=0.01$

Labels for Tukey's HSD test: difference between values with the same letter is not significant at the level $\alpha=0.05$ 
Table 3. Continue.

\begin{tabular}{|c|c|c|c|c|c|c|c|}
\hline & & TRN & R0p & R05p & R5p & R510p & R1020p \\
\hline \multicolumn{8}{|c|}{ F-test } \\
\hline \multicolumn{2}{|l|}{ Clone (A) } & $12.03^{* *}$ & $5.03 * *$ & $7.47^{* *}$ & 1.44 & 0.21 & $4,37 *$ \\
\hline \multicolumn{2}{|l|}{ Term (B) } & $9.54^{* *}$ & $12.16^{* *}$ & $7.28^{* *}$ & 0.98 & 1.33 & 0,02 \\
\hline \multicolumn{2}{|c|}{ Interaction $\mathrm{A} \times \mathrm{B}$} & $15,33^{* *}$ & $4.03 *$ & $3.65 *$ & $3.50 *$ & 1.31 & 1.59 \\
\hline \multicolumn{8}{|c|}{ Tukey's HSD-test } \\
\hline Villafranca & & $12.17 \mathrm{~b}$ & 42.49 a & $9.76 \mathrm{~b}$ & 56.64 a & $17.16^{a}$ & 20.85 a \\
\hline L-12 & & $10.94 \mathrm{~b}$ & 33.17 a & 20.73 a & 64.66 a & 17.29 a & $12.82 \mathrm{ab}$ \\
\hline \multirow[t]{3}{*}{$\mathrm{L}-80$} & & $18.64^{a}$ & $49.43^{a}$ & $15.00 \mathrm{ab}$ & 69.99 a & $15.28{ }^{a}$ & $9.07 \mathrm{~b}$ \\
\hline & $\begin{array}{l}\text { Mid } \\
\text { March }\end{array}$ & 15.66 a & 49.49 a & 13.02 a & 68.07 a & 14.71 a & 12.54 a \\
\hline & $\begin{array}{l}\text { Early } \\
\text { April }\end{array}$ & $11.48 \mathrm{~b}$ & $32.05 \mathrm{~b}$ & 16.03 a & 56.38 a & 19.42 a & 17.01 a \\
\hline Villafranca & $\begin{array}{l}\text { Mid } \\
\text { March }\end{array}$ & 20.07 a & 61.99 a & $10.66^{b}$ & 73.23 a & 11.27 a & $15.10 \mathrm{ab}$ \\
\hline Villafranca & $\begin{array}{l}\text { Early } \\
\text { April }\end{array}$ & $6.91^{c}$ & $26.71 \mathrm{bc}$ & $9.02 \mathrm{~b}$ & $41.83 \mathrm{~b}$ & 22.91 a & 26.25 a \\
\hline L-12 & $\begin{array}{l}\text { Mid } \\
\text { March }\end{array}$ & $12.00 \mathrm{bc}$ & $39.83 \mathrm{abc}$ & $16.36 \mathrm{ab}$ & $64.19 \mathrm{ab}$ & 16.63 a & $14.11 \mathrm{ab}$ \\
\hline L-12 & $\begin{array}{l}\text { Early } \\
\text { April }\end{array}$ & $6.12^{c}$ & $6.16^{c}$ & $48.34^{\mathrm{a}}$ & $67.12 \mathrm{ab}$ & 20.89 a & $6.96 \mathrm{ab}$ \\
\hline L-80 & $\begin{array}{l}\text { Mid } \\
\text { March }\end{array}$ & $16.25 \mathrm{ab}$ & $48.96 \mathrm{ab}$ & $11.74^{b}$ & $67.58 \mathrm{ab}$ & $15.90^{a}$ & $8.92 b$ \\
\hline L-80 & $\begin{array}{l}\text { Early } \\
\text { April }\end{array}$ & $22.13^{a}$ & $50.06^{a b}$ & $19.92 \mathrm{ab}$ & $73.19 \mathrm{ab}$ & $14.45^{\mathrm{a}}$ & $9.26 \mathrm{ab}$ \\
\hline
\end{tabular}

Labels of traits: TRN - total number of roots; R0p - partition of number of roots on basal cut in total number of roots; R05p - partition of number of roots from basal cut to $5^{\text {th }} \mathrm{cm}$ from base of cutting in total number of roots, R5p - partition of number of roots below $5^{\text {th }} \mathrm{cm}$ from the base of cutting in total number of roots; R510p - partition of number of roots from $5^{\text {th }}$ to $10^{\text {th }} \mathrm{cm}$ from the base of cutting in total number of roots; R1020 $\mathrm{p}$ - partition of number of roots from $10^{\text {th }} \mathrm{cm}$ to the top of cutting in total number of roots

Labels for F-test: * - significant at the level $\alpha=0.05$; ** - significant at the level $\alpha=0.01$

Labels for Tukey's HSD test: difference between values with the same letter is not significant at the level $\alpha=0.05$

The effect of interaction Clone $\times$ Term was also significant in most of examined rooting parameters, suggesting differences between clones in their reaction on examined terms. The greatest F-values were found for R0, R05, R5, TRN and SH (around 10 and higher). For most of these parameters the difference between two examined terms were significant only in Villafranca (values were significantly higher after mid-March preparation and planting), except for R05 in L-80 (significantly lower value after mid-March preparation and planting). Villafranca also achieved significantly higher number of roots on upper portion of cutting (R1020) after midMarch cuttings' preparation and planting and higher partition of number of roots on basal cut and on part of cutting below its $5^{\text {th }} \mathrm{cm}$ from the basal cut in total number of roots (R0p and R5p). 


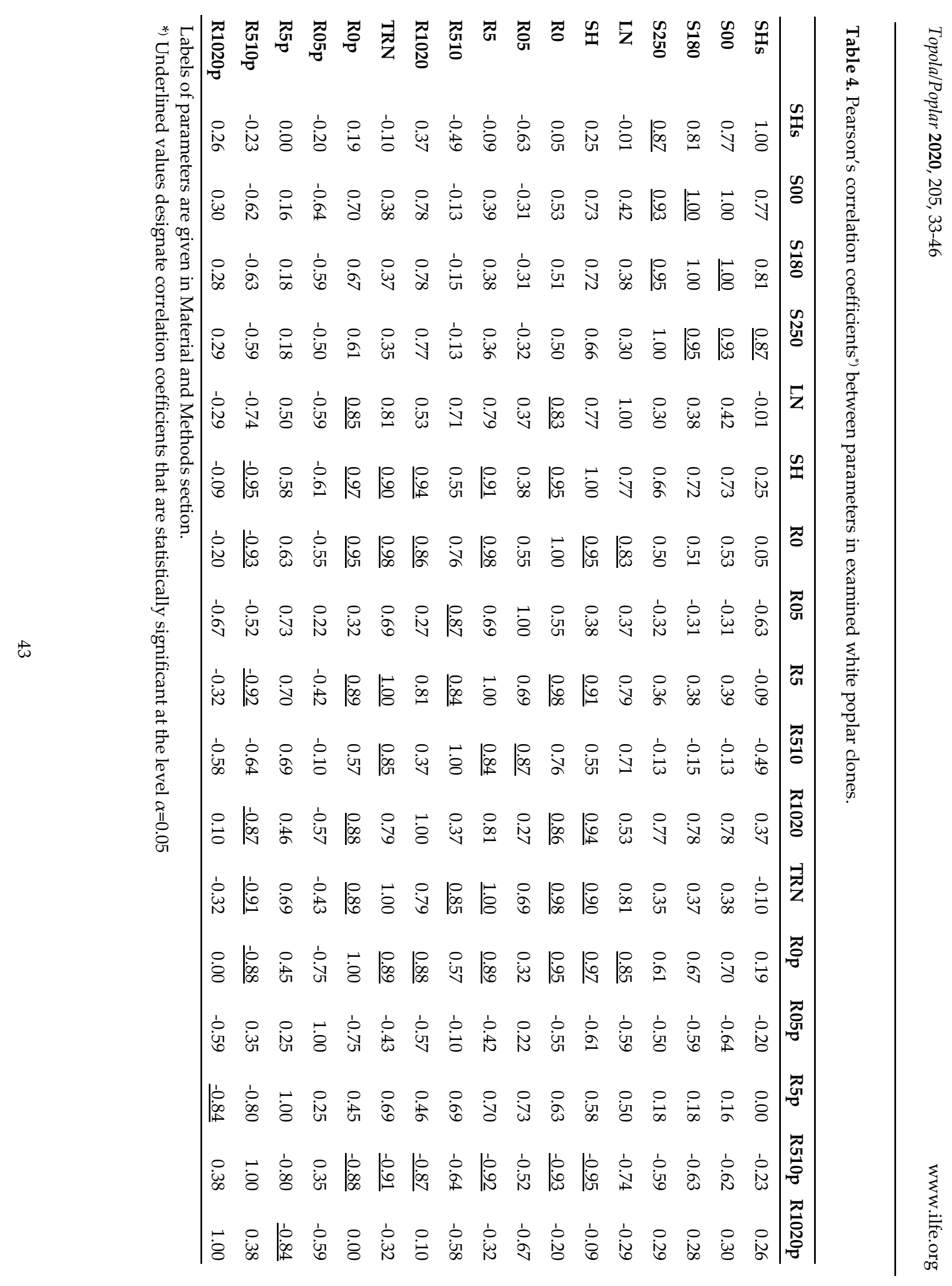


Thus, according to rooting characteristics, the strongest and only significant positive reaction on earlier term of cuttings preparation and planting achieved Villafranca by better shoot growth and rooting, especially in basal portion of cutting. That is not in correspondence with cuttings' survival in trial in "Kaćka šuma", by which both Villafranca and L-12 clones achieved significantly better cuttings survival after earlier term of cuttings' preparation and planting, suggesting that this matter should be further studied.

According to Kovačević et al. (2008), the rooting at the middle part of cutting as well as of the shoot height at the beginning of June was closely related to survival of rooted cuttings in black poplar clones. In our study, there was not found a significant correlation between any of examined growth or survival parameters and any of examined rooting characters (Table 4). Shoot height was in high but statistically not significant correlation with cuttings' survival, suggesting need for further work on this subject in white poplar. Close positive relationship between shoot height and cuttings' survival is supported by the results of Kovačević et al. (2008). In our work, shoot height was in significant positive correlation with numerous other rooting characters such as: R0, R5, R1020, TRN, R05p and in negative correlation with R510p. The negative correlation between shoot height and partition of roots on middle part of cutting (R510p) does not correspond to the results of Kovačević et al. (2008), who found this correlation to be positive in black poplar clones. The relationship between shoot height and parameters that describe root system could be used in further efforts of breeding improvement and optimization of white poplar nursery technology and deserves further research.

\section{Final remarks}

This work emphasizes the importance of early term (mid-March) of cuttings' preparation and planting, suggesting that this term provides not only possibility to extend period of the establishment of white poplar nursery production but better results. Relatively good survival and growth of rooted cuttings planted at early term that are at the level or even better than of those planted in traditionally used term at the beginning of April could be related to the fact that, according to the report of Republic Hydrometeorological Service of Serbia (2020), last ten years (2010-2019) are characterized by higher temperatures and lower precipitation than the normals (1981-2010). Zalesny et al. (2004) suggest that planting of Populus cuttings should not be performed by calendar days but by actual and predicted soil temperatures, which is in concordance with expected climate changes. So, regarding the importance of soil temperature in poplar cuttings' rooting (Zalesny et al. 2004; Zalesny et al. 2005) it could be expected that the optimal terms for white poplar cuttings' preparation and planting appear to be earlier that it used to be ten years ago.

Regarding warmer winters, the earlier end of dormancy could also be expected. Eggens et al. (1972) suggest that dormancy of cutting decrease during the winter, while results of Kovačević (2003), Andrašev et al. (2006) and Kovačević et al. (2006) stress the importance of at least some level of dormancy in cuttings of euramerican poplar, assuming that better rooting of more dormant cuttings could be related to longer period between root initiation and bud burst. In concordance with them, Kovačević et al. (2018) suggest preservation of dormant state of white poplar cuttings by early cuttings preparation and their storage on low temperature if they have to be planted in later terms. However, according to Kovačević et al. (2006), even storage of black poplar cuttings at low temperatures could not be sufficient to ensure feasible results if those cuttings are planted in too late terms (like in late April).

\section{Acknowledgments}

This study was financed by the Ministry of Education, Science and Technological Development of the Republic of Serbia (Project No: 451-03-68/2020-14/200197). 


\section{References}

1. Andrašev, S., Kovačević, B., Rončević, S., Ivanišević, P., Đanić, I., Tadin, Z. (2006): Effect of the terms of production and planting on the survival of euramerican poplar cuttings. International Scientific Conference "Sustainable Use of Forest Ecosystems - The Chalenge of 21st Century", 8-10 November, Donji Milanovac, Serbia: 182-187.

2. De Almeida, M.R., Aumond, M.Jr., Da Costa, C.T., Schwambach, J., Ruedell, C.M., Correa, L.R., Fett-Neto, A.G. (2017): Environmental control of adventitious rooting in Eucaliptus and Populus cuttings. Trees - Structure and Function 31: 1377-1390

3. Eggens, J.L., Lougheed, E.C., Hilton, R.J. (1972): Rooting of hardwood cuttings of boleana poplar. Canadian Journal of Plant Science 52: 599-604.

4. Fege, S. (1983): The practice and physiological basis of collecting, storing and planting Populus hardwood cuttings. USDA, Gen. Tech. Report. 91: 11p.

5. Guzina, V., Božić, J., Tomović, Z. (1986): Poplars of the Leuce Duby section (White poplars and aspens). In: Guzina V (ed). Poplars and willows in Yugoslavia. Poplar Research Institute, Novi Sad, Yugoslavia. pp. 74-85.

6. Igić, D., Borišev, M., Vilotić, D., Šijačić-Nikolić, M., Ćuk, M., Ilić, M., Kovačević, B. (2020): Variability and relationships among rooting characteristics for white poplar hardwood cuttings. Archives of Biological Sciences (on line); https://doi.org/10.2298/ABS200114008I.

7. Ištok, I., Šefc, B., Sedlar, T., Goršić, E., Mihić, M., Stojnić, S. (2019): Fiber length in clone 'L-12' juvenile wood. Topola 203: 37-43.

8. Kovačević B. (2003): Genetička divergentnost obrazovanja vegetativnih organa crnih topola (sekcija Aigeiros Duby). [Genetic diversity of vegetative organs' development in black poplars (section Aigeiros Duby). PhD thesis, University of Novi Sad, Faculty of Agriculture, Novi Sad: 173 pp. [In Serbian]

9. Kovačević B., Guzina V., Andrašev S. (2002): Varijabilnost topola u pogledu sposobnosti za ožiljavane njihovih reznica od pruta. Topola 169/170: 23-36.

10. Kovacevic, B., Guzina, V., Kraljevic-Balalic, M., Ivanovic, M., Nikolić-Đorić, E. (2008a): Evaluation of early rooting traits of eastern cottonwood that are important for selection tests. Silvae genetica 57(1): 13-21.

11. Kovačević, B, Igić, D. (2018): Effect of early preparation and slope aspect on survival and growth of white poplar rooted cuttings. Topola 201/202: 117-126.

12. Kovačević, B., Orlović, S., Pap, P., Katanić, M., Dabić, S. (2014): Efekat primene praškastih formulacija sa kobalt hloridom i indolbuternom kiselinom na ožiljavanje drvenastih reznica bele topole. Topola 193/194: 117-127.

13. Kovačević, B, Orlović, S, Pekeč, S, Katanić, M, Stojnić, S (2010): The effect of genotype and date of preparation on rooting of white poplar cuttings. Proceedings from First Serbian forestry congress: Future with forest, 11-13 November, Belgrade, Serbia: 306-311.

14. Kovacevic, B., Orlovic, S., Roncevic, S., Ivanisevic, P., Klasnja, B. (2008b): Significance of genotype, date of cutting preparation and planting, soil and year for survival and growth of black poplar rooted cuttings. Proceedings of $16^{\text {th }}$ European Biomass Conference \& Exibition, 2-6 June 2008, Valencia, Spain: 614-617.

15. Kovačević, B., Rončević, S., Andrašev, S., Pekeč, S. (2006): Effects of date of preparation, date of planting and storage type on cutting rooting in euramerican poplar. International Scientific Conference "Sustainable Use of Forest Ecosystems - The Chalenge of 21 st Century", 8-10 November, Donji Milanovac, Serbia: 42- 46

16. Kovacevic, B., Roncevic, S., Miladinovic, D., Ivanisevic, P., Katanic, M. (2009): Early shoot and root growth dynamics as indicators for the survival of black poplar cuttings. New Forests 38: 177-185. 
17. Pacurar, I, Perrone, I, Bellini, C. (2014): Auxin is a central player in the hormone crosstalks that control adventitious rooting. Physiologia Plantarum 151: 83-96.

18. R Core Team (2017): R: A language and environment for statistical computing. R Foundation for Statistical Computing, Vienna, Austria.

19. Republic Hydrometeorlogical Service of Serbia (2020): Annual bulletin for Serbia the year of 2019, http://www.hidmet.gov.rs/podaci/meteorologija/eng/2019.pdf

20. Rončević, S., Andrašev, S., Ivanišević, P., Kovačević, B., Novčić, Z. (2012): Effect of variability of alluvial soil properties on growth of white poplars Populus alba L. cl. L-12. Proceedings of International Scientific Conference „Forest in future: Sustainable Use, Risks and Challenges", 4-5 October, Belgrade, Serbia: 469-475.

21. Sedlar, T., Ištok, I., Orešković, G., Stojnić, S., Goršić, E., Šefc, B. (2019). Physical properties of wood in white poplar clone 'L-12' grown in Republic of Croatia and Serbia. Topola 203: 45-51.

22. Smith, N.G., Wareing, P.F. (1972): The distribution of latent root primordia in stems of Populus $x$ robusta and factors affecting the emergence of preformed roots from cuttings. Forestry 45: 197-209.

23. Stage, A.R., Salas, C. (2007): Interactions of elevation, aspect and slope in models of forest species composition and productivity. Forest Science 53(4): 486-492.

24. TIBCO Software Inc. (2017). Statistica (data analysis software system), version 13. http://statistica.io.

25. Zalesny, R.S.Jr., Bauer, E.O., Reimenschneider, D.E. (2004): Use of belowground growing degree days to predict rooting of dormant hardwood cuttings of Populus. Silvae Genetica 53(4-5): 154-160.

26. Zalesny, R.S., Hall, R.B., Bauer, E.O., Riemenschneider, D.E. (2005): Soil temperature and precipitation affect the rooting ability of dormant hardwood cuttings of Populus. Silvae Genetica 54(2): 47-58.

27. Zhao, X., Zheng, H., Li, S., Yang, C., Jiang, J., Liu, G. (2014): The rooting of poplar cuttings: a review. New Forests 45: 21-34. 